\title{
Research on the reinforcement measures of close-parallel tunnels
}

\author{
Li Meng ${ }^{1}, \mathrm{Hu}$ Ping $^{1}$, and Ma Liang ${ }^{1}$ \\ ${ }^{1}$ School of Civil Engineering and Architecture, University of Jinan, Jinan 250022, China
}

\begin{abstract}
Based on shallow parallel underground tunnel and double-line shield tunnel of Jinan Rail Transit Line R3, this paper proposes two reinforcement measures including bored piles and curtain grouting in the middle of the tunnel, making a numerical analysis and comparison of the reinforcement effect. The results show that the influence of later tunnel construction on the deformation of earlier tunnel can be effectively reduced after taking two reinforcement measures respectively and the reinforcement effect of the bored piles is better.
\end{abstract}

\section{Introduction}

With the increase in parallel construction of small-pitch tunnels ${ }^{[1]}$, the resulting engineering risks and construction difficulties are also increasing ${ }^{[2-6]}$. For small-pitch tunnels, especially small-pitch tunnel groups constructed by different construction methods (such as shield tunnels and shallow buried tunnels), the squeezing and unloading effect of the later tunnel on the earlier tunnel will cause great disturbance to the earlier tunnel structure and surrounding rock and soil bodies, thus affecting the stability and safety of the tunnel. When the clear distance of the tunnel is too small, certain reinforcement measures should be taken to increase the stability of the surrounding rock, so as to reduce the deformation of the surrounding rock of the tunnel and reduce the risk of the tunnel. Therefore, it is of great engineering significance to study the reinforcement measures of tunnels under the condition of small clear distance parallel construction.

Based on shallow parallel underground tunnel and double-line shield tunnel of Jinan Rail Transit Line R3, this paper proposes two methods for the construction and reinforcement of small-pitch tunnels suitable for this project, namely curtain grouting method and drilling bored pile method. MIDAS/GTS software is used to numerically simulate the two reinforcement methods and analyze the reinforcement effects. It will provide technical support and reference for similar projects in the future.

\section{Project Overview}

The section between Longdongzhuang Station and Mengjiazhuang Station of Jinan Rail Transit Line R3 consists of three parallel tunnels. The tunnel in the middle adopts shallow burying method (CD construction method), which is divided into two guide tunnels $A$ and $\mathrm{B}$ to be constructed first. After that, the tunnels on both sides are constructed by shield method. The left line goes first, and the right line follows. During excavation, the two lines are bilaterally symmetrical and are at the same level as the previous shallow buried tunnel. And the horizontal clear distance gradually decreases. The minimum horizontal clear distance is only $2.55 \mathrm{~m}$, which is much smaller than the tunnel diameter. The tunnel section layout is shown in Figure 1.

The structure of the shallow buried tunnel is a single-hole, two-line horseshoe tunnel with a cross-section clearance of $11.7 \times 8.59 \mathrm{~m}$ (width $\times$ height). The tunnel section is divided into two small guide tunnels and excavated successively with CD construction method. And the tunnel shall be supported in advance before it is excavated. Two shield machines are selected in the shield tunnel section, where the left line goes first and the right line is behind, starting from the long-mile end of Longdong Station. The diameter of the shield tunnel is $6.4 \mathrm{~m}$ and the thickness of the segment is $0.3 \mathrm{~m}$. Cement mortar is used as the synchronous grouting material in the shield tunnel.

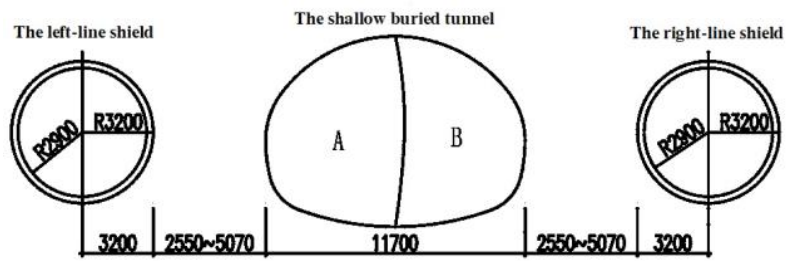

Fig. 1. Sectional view of three-hole small clear distance tunnel

\section{Reinforcement measures and effect analysis}

\subsection{Reinforcement measures}

For the three-hole small-pitch tunnels in this project,

* Corresponding author: pinghu2002@163.com 
when the shields on both sides of the tunnel are under construction, it can no longer meet the safety requirements that only supporting the intermediate tunnel or adjusting and optimizing the shield construction parameters through monitoring data. Certain reinforcement measures should be taken in the middle stratum of the tunnel, more importantly. On the basis of summarizing the existing reinforcement measures, the actual engineering conditions and the feasibility of construction, two types of reinforcement measures are proposed: (1) Curtain grouting reinforcement in the middle stratum; (2) Drilling and pouring piles are reinforced in the middle stratum.

\subsection{Model establishment and parameter selection}

MIDAS/GTS software is used for numerical simulation. The equivalent parameters of the rock-soil body and supporting structure before reinforcement are shown in Table 1, and the Mohr-Coulomb elastoplastic model is used for the soil constitutive model. The properties of the reinforced soil are obtained by adjusting the physical and mechanical parameters of the soil. And the parameters of the intermediate stratum after reinforcement are shown in Table 2. The model size is selected to be $100 \mathrm{~m} \times 60 \mathrm{~m}$ (width $\times$ height). And the clear distance between tunnels is $0.8 \mathrm{D}$. The models of curtain grouting and cast-in-place bored piles are established as shown in Figure 2 and Figure 3 respectively.

Table. 1. Equivalent parameters of soils and supporting structure before reinforcement

\begin{tabular}{|c|c|c|c|c|c|c|c|}
\hline Material layer & $\begin{array}{c}\text { Mass density } \\
(\mathrm{kN} / \mathrm{m} 3)\end{array}$ & $\begin{array}{c}\text { Internal friction } \\
\text { angle }\left(^{\circ}\right)\end{array}$ & $\begin{array}{c}\text { Cohesion } \\
(\mathrm{kPa})\end{array}$ & $\begin{array}{c}\text { Lateral pressure } \\
\text { coefficient }\end{array}$ & $\begin{array}{c}\text { Thickness } \\
(\mathrm{m})\end{array}$ & $\begin{array}{c}\text { Elastic Modulus } \\
(\mathrm{MPa})\end{array}$ & $\begin{array}{c}\text { Poisson's } \\
\text { ratio }\end{array}$ \\
\hline plain fill & 18.90 & 15.00 & 20.00 & 0.38 & 0.80 & 47.48 & 0.40 \\
\hline silty clay & 18.90 & 13.10 & 20.30 & 0.41 & 8.60 & 45.46 & 0.29 \\
\hline gravel soil & 21.00 & 38.00 & 10.00 & 0.25 & 7.60 & 73.63 & 0.20 \\
\hline medium-weathered limestone & 26.90 & 39.00 & 700.00 & 0.18 & 43.00 & $3.23 \times 10^{4}$ & 0.18 \\
\hline $\begin{array}{c}\text { Advanced small catheter } \\
\text { reinforcement area }\end{array}$ & 21.00 & 38.00 & 100.00 & 0.28 & 0.80 & 100.00 & 0.22 \\
\hline shield segment & 25.00 & $/$ & $/$ & $/$ & 0.30 & $2.23 \times 10^{4}$ & 0.20 \\
\hline equivalent layer & 25.00 & $/$ & $/$ & $/$ & 0.15 & 1.20 & 0.20 \\
\hline initial support & 22.00 & $/$ & $/$ & $/$ & 0.35 & $1.5 \times 10^{4}$ & 0.20 \\
\hline initial support hardening & 22.00 & $/$ & $/$ & $/$ & 0.35 & $3.0 \times 10^{4}$ & 0.40 \\
\hline
\end{tabular}

Table.2. Equivalent parameters of reinforced soil

\begin{tabular}{|c|c|c|c|c|}
\hline Material layer & $\begin{array}{c}\text { Mass density } \\
(\mathrm{kN} / \mathrm{m} 3)\end{array}$ & $\begin{array}{c}\text { Internal friction } \\
\text { angle }\left(^{\circ}\right)\end{array}$ & $\begin{array}{c}\text { Cohesion } \\
(\mathrm{kPa})\end{array}$ \\
\hline $\begin{array}{c}\text { the section of curtain } \\
\text { grouting } \\
\text { reinforcement }\end{array}$ & 21.00 & 38.00 & 100.00 \\
\hline $\begin{array}{c}\text { The section of bored } \\
\text { cast-in-place piles } \\
\text { reinforcement }\end{array}$ & 22.00 & 36.00 & 100.00 \\
\hline $\begin{array}{c}\text { Material layer } \\
\text { pressure } \\
\text { coefficient }\end{array}$ & Thickness & $\begin{array}{c}\text { Elastic } \\
\text { (m) }\end{array}$ & $\begin{array}{c}\text { Modulus } \\
\text { (MPa) }\end{array}$ & Poisson's ratio \\
\hline $\begin{array}{c}\text { grouting } \\
\text { reinforcement }\end{array}$ & 0.28 & 6.40 & 100.00 & \\
\hline the section of curtain & & & \\
\hline
\end{tabular}
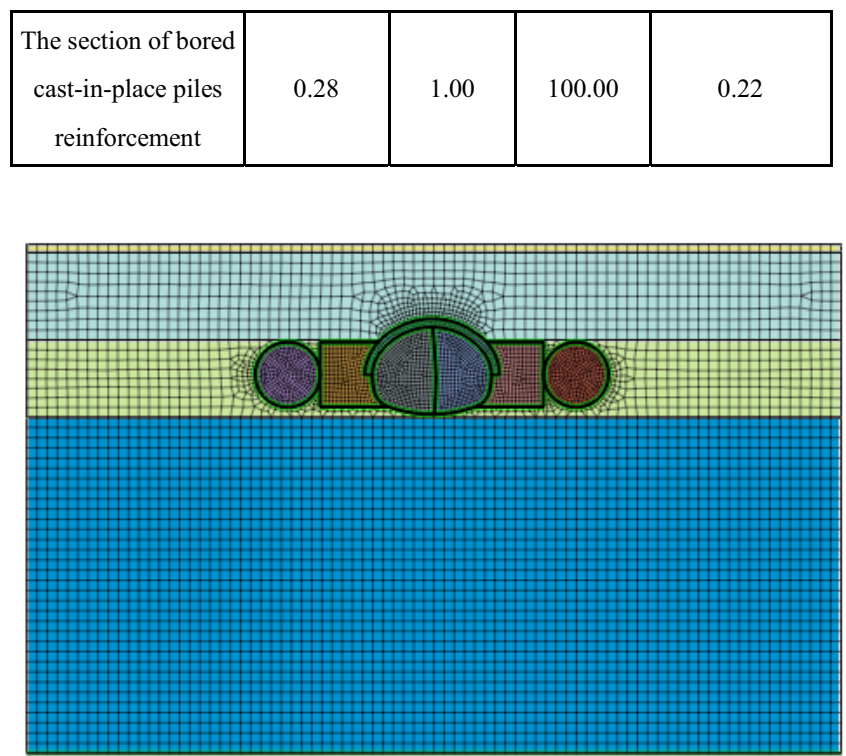

Fig.2. reinforced model of curtain grouting 


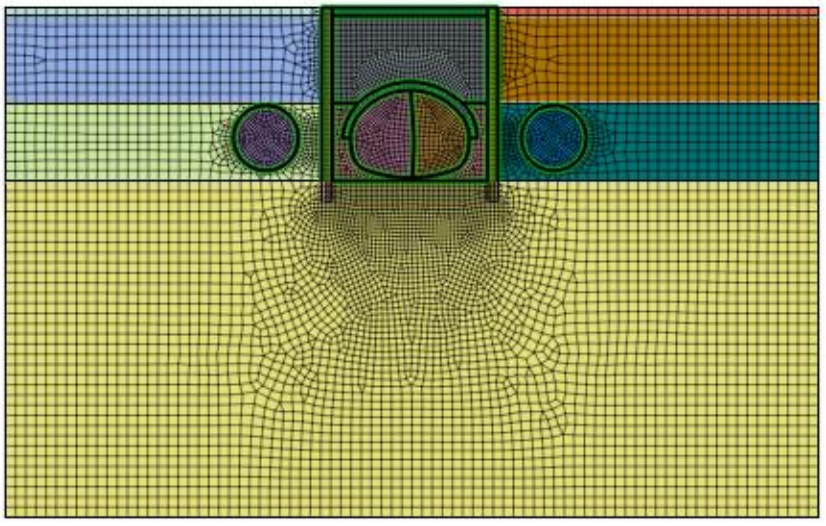

Fig.3. Reinforced model of bored cast-in-place piles

\subsection{Effect analysis of different reinforcement schemes}

\subsubsection{Horizontal displacement}

Table 3 shows the headroom convergence values of the middle leading tunnel under different reinforcement conditions during tunnel excavation on both sides. It can be seen from Table 3 that the headroom convergence values of the $\mathrm{A}$ and $\mathrm{B}$ holes of the intermediate tunnel will change greatly after the construction of the shield tunnels on the left and right sides is completed, if no reinforcement measures are taken before. However, the clearance of the intermediate tunnels $\mathrm{A}$ and $\mathrm{B}$ will not change much compared with the initial support if curtain grouting and bored piles are used for reinforcement. It shows that both of two schemes can effectively reduce the influence of the horizontal deformation of the preceding tunnel during the construction of the following tunnel.

Table. 3. Clearance Convergence of the shallow buried tunnel

\begin{tabular}{|c|c|c|c|c|}
\hline \multirow[b]{2}{*}{$\begin{array}{l}\text { Working } \\
\text { condition }\end{array}$} & \multirow[b]{2}{*}{ Position } & \multicolumn{3}{|c|}{ Clearance convergence $(\mathrm{mm})$} \\
\hline & & $\begin{array}{l}\text { Unreinf- } \\
\text { orced }\end{array}$ & $\begin{array}{l}\text { Curtain } \\
\text { grouting }\end{array}$ & $\begin{array}{c}\text { Bored } \\
\text { cast-in-plac } \\
\text { e piles }\end{array}$ \\
\hline \multirow{2}{*}{$\begin{array}{c}\text { Excavation of the } \\
\text { middle tunnel }\end{array}$} & Hole A & 6.46 & 1 & 1 \\
\hline & Hole B & -5.27 & 1 & 1 \\
\hline \multirow{2}{*}{$\begin{array}{c}\text { Reinforcement } \\
\text { measures } \\
\text { construction }\end{array}$} & Hole A & 1 & 7.05 & 6.51 \\
\hline & Hole B & 1 & -5.66 & -5.30 \\
\hline \multirow{2}{*}{$\begin{array}{c}\text { Excavation of the } \\
\text { left tunnel }\end{array}$} & Hole A & 4.97 & 6.74 & 6.32 \\
\hline & Hole B & -5.12 & -5.65 & -5.31 \\
\hline \multirow{2}{*}{$\begin{array}{c}\text { Excavation of the } \\
\text { right tunnel }\end{array}$} & Hole A & 4.80 & 6.72 & 6.33 \\
\hline & Hole B & -4.03 & -5.33 & -5.17 \\
\hline
\end{tabular}

It can also be found from Table 3 that the clearance of holes A and B of the middle tunnel has increased compared with the horizontal displacement during construction when curtain grouting is applied to the middle stratum. This shows that curtain grouting in the middle stratum will cause the tunnel surrounding rock to move into the tunnel. And the reason is that the pressure of the initial support of the soil around the intermediate tunnel increases due to the vibration of the machine and the pressure of grouting when drilling. As a result, the horizontal displacement of the soil increases and the surrounding rock moves inward. However, the deformation of the intermediate tunnel is relatively small when using bored piles for reinforcement, because the influence range of the slurry pressure is small and the distance between the pile and the tunnel is large.

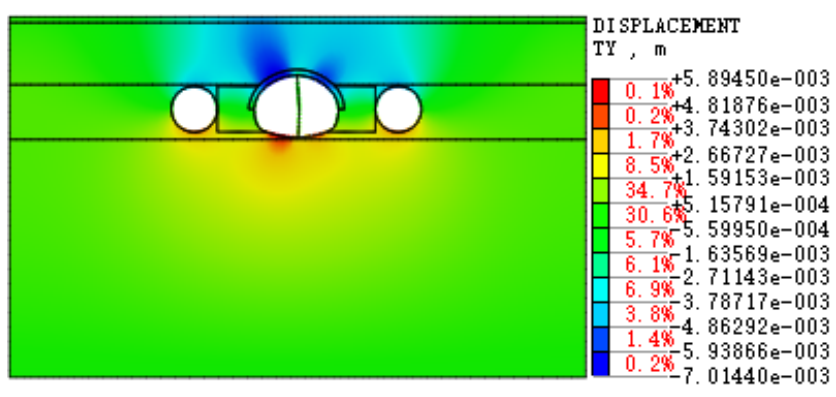

Fig. 4. Vertical displacement cloud image of the middle tunnel under the curtain grouting scheme

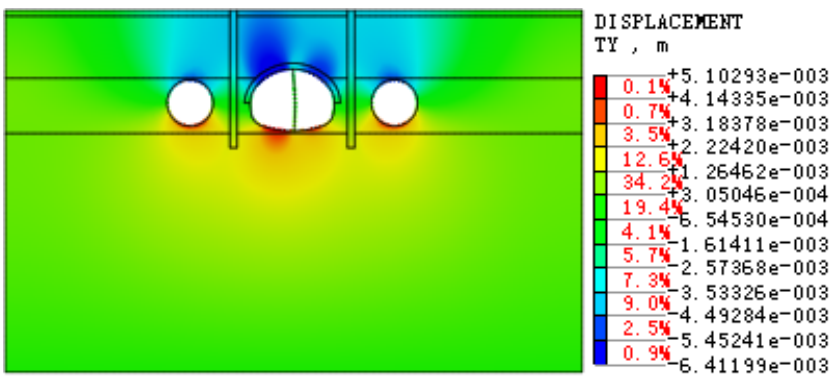

Fig. 5. Vertical displacement cloud image of the middle tunnel under the bored pile scheme

\subsubsection{Vertical displacement}

Figure 4 and Figure 5 are the vertical displacement clouds of the three-hole tunnel under different reinforcement conditions. It can be seen that the cloud settlement of the vault of the three-hole tunnel will still overlap with that of the upward arch uplift if curtain grouting is used to reinforce the middle stratum at the same level in the three-hole tunnel. And this means that the excavation of the back shield tunnel at this time will still affect the vertical deformation of the previous tunnel. However, the vault settlement map is shown as three unrelated parts due to the splitting effect of the piles when bored piles are installed in the middle stratum. At this time, the impact of the excavation of the later shield tunnel on the vertical displacement of the earlier tunnel will be greatly reduced.

Table 4 shows the vault settlement and invert arch uplift values of the middle tunnel under different reinforcement conditions during the excavation of the tunnels on both sides. It can be seen from Table 4 that the settlement and vaulting of the vault of the first shallow buried tunnel are greatly reduced compared with the case without reinforcement when curtain grouting and bored cast-in-place piles are used for reinforcement. And it means that both of two kinds of reinforcement 
measures can effectively reduce the influence of the vertical deformation of the first shallow buried tunnel when the subsequent shield tunneling. In comparison, the numerical value of the measures for drilling bored piles is greater, which means that the reinforcement of the measures for drilling bored piles can better control the vertical displacement of the first shallow buried tunnel.

Table. 4. Vertical displacement of the early shallow buried tunnel

\begin{tabular}{|c|c|c|c|}
\hline \multirow{3}{*}{$\begin{array}{l}\text { Working } \\
\text { condition }\end{array}$} & \multirow{2}{*}{\multicolumn{3}{|c|}{ Vault settlement (mm) }} \\
\hline & & & \\
\hline & $\begin{array}{l}\text { Unreinforce } \\
\text { d }\end{array}$ & $\begin{array}{l}\text { Curtain } \\
\text { grouting }\end{array}$ & $\begin{array}{c}\text { Bored } \\
\text { cast-in-plac } \\
\text { e piles } \\
\end{array}$ \\
\hline $\begin{array}{l}\text { Excavation of } \\
\text { the middle } \\
\text { tunnel }\end{array}$ & -6.17 & 1 & 1 \\
\hline $\begin{array}{c}\text { Reinforcement } \\
\text { measures } \\
\text { construction }\end{array}$ & 1 & -6.34 & -6.18 \\
\hline $\begin{array}{l}\text { Excavation of } \\
\text { the left tunnel }\end{array}$ & -7.67 & -6.92 & -6.32 \\
\hline $\begin{array}{l}\text { Excavation of } \\
\text { the right tunnel }\end{array}$ & -9.12 & -7.42 & -6.41 \\
\hline \multirow[b]{2}{*}{$\begin{array}{l}\text { Working } \\
\text { condition }\end{array}$} & \multicolumn{3}{|c|}{ Uplift (mm) } \\
\hline & $\begin{array}{l}\text { Unreinforce } \\
\text { d }\end{array}$ & $\begin{array}{l}\text { Curtain } \\
\text { grouting }\end{array}$ & $\begin{array}{c}\text { Bored } \\
\text { cast-in-plac } \\
\text { e piles }\end{array}$ \\
\hline $\begin{array}{l}\text { Excavation of } \\
\text { the middle } \\
\text { tunnel }\end{array}$ & 4.98 & 1 & 1 \\
\hline $\begin{array}{c}\text { Reinforcement } \\
\text { measures } \\
\text { construction }\end{array}$ & 1 & 5.20 & 4.98 \\
\hline $\begin{array}{l}\text { Excavation of } \\
\text { the left tunnel }\end{array}$ & 6.41 & 5.37 & 5.07 \\
\hline $\begin{array}{l}\text { Excavation of } \\
\text { the right tunnel }\end{array}$ & 8.09 & 5.98 & 5.10 \\
\hline
\end{tabular}

From the above analysis, it can be seen that curtain grouting in the middle of the stratum and the construction of bored piles both can effectively reduce the impact of the deformation of the first shallow buried tunnel when the subsequent shield tunneling. However, the surrounding rock moves into the middle tunnel because of the curtain grouting scheme. At the same time, the vertical displacement of the three-hole tunnel still overlaps. And the horizontal displacement, vault settlement and uplift of the leading tunnel in the middle of the shield tunnel excavation on both sides are bigger than those under the measures of drilling and pouring piles. It is proved that the use of drilling bored piles can better control the deformation effect of the subsequent shield excavation on the first shallow buried tunnel.

\section{Conclusions}

Based on the analysis of deformation control measures of small spacing tunnel, two reinforcement measures, namely curtain grouting method and bored pile method, which are suitable for the project, are put forward. Through the analysis of the two reinforcement methods by the use of MIDAS/GTS software, it can be seen that curtain grouting in the middle of the stratum and the construction of bored piles both can effectively reduce the impact of the deformation of the first shallow buried tunnel when the subsequent shield tunneling. In comparison, the use of bored piles can better control the deformation and displacement of the first shallow buried tunnel. Although the tunnel clearance decreases, the deformation of the first shallow buried tunnel is still slightly increased when the next shield tunnel is excavated after the bored piles are installed. But the change is not significant and is far less than its deformation control value. And the plastic zone no longer overlaps, which makes the construction of ultra-small clearance safe.

\section{Acknowledgements}

This research was financially supported by the National Natural Science Foundation of China under Grant No. 51979122.

\section{References}

1. Chen Z H. Simulation Analysis About Construction Technology of the Shielding Tunnel Nearby the Shallow Buried Tunnel in Parallel Overlapped Section. Railway Construction Technology. 9, 62-65+83 (2017)

2. Fang Y S, Lin J S, Su C S. An estimation of ground settlement due to shield tunnelling by the Peck-Fujita method. Canadian geotechnical journal. 31(3), 431-443 (1994)

3. Wang H X, Wu J, Tan Y Z, Zuo Q J, Ming H J. Mutual Turbulence Analysis for Parallel Tunnel Construction of Shield and Mine Tunneling Methods. Journal of Engineering Geology. 25(2), 344-351 (2017)

4. Zheng Y C. Study on the influence degree of adjacent construction of three parralell shield tunnels (Chengdu: Southwest Jiaotong University) (2007)

5. Kim S H. Interaction behaviours between parallel tunnels in soft ground. Tunneling and Underground Space Technology. 19(4-5), 448 (2004)

6. Zhang C. Analysis on structural force characteristics of three holes parallel small interval tunnel. Shanxi Architecture. 39(2), 172-173 (2013) 